\title{
STUDY OF HIGH SPECIFIC C-REACTIVE PROTEIN IN ACUTE ISCHAEMIC STROKE
}

\author{
Madhan Kumar Subbarayan ${ }^{1}$, Chinnaiyan P2, Sravankumar Sampati ${ }^{3}$
}

1 Postgraduate Resident, Department of General Medicine, Sri Venkateshwara Medical College Hospital and Research Centre, Ariyur, Puducherry, India.

2Professor and HOD, Department of General Medicine, Sri Venkateshwara Medical College Hospital and Research Centre, Ariyur, Puducherry, India.

${ }^{3}$ Postgraduate, Department of General Medicine, Sri Venkateshwara Medical College Hospital and Research Centre, Ariyur, Puducherry, India. ABSTRACT
BACKGROUND
We wanted to study the highly specific C-reactive protein in acute ischaemic stroke and examine the acute ischaemic stroke
patients in a region, against their CRP levels for stroke prognosis.

\section{METHODS}

This study was an observational study. The study was conducted at in Venkateshwara Medical College \& Hospital. The sample size taken for the study is $n=100$ patients.

\section{RESULTS}

The association of highly specific $\mathrm{C}$ reactive protein with diabetes mellitus showed chi square $6.803, \mathrm{p}<0.01$, with cholesterol level chi square 9.425, $\mathrm{p}<0.01$, with hypertension chi square 4.191, $\mathrm{p}<0.05$, with ischaemic heart disease $\mathrm{p}<0.01$, with smoking $\mathrm{p}<0.01$, with alcoholism $\mathrm{p}<0.01$, with angina $\mathrm{p}<0.01$.

\section{CONCLUSIONS}

The findings of the present study indicate that regulating the level of CRP will help to decrease the risk of acute schematic stroke. The study concludes that high hsCRP level predicts the chance of higher level of acute ischaemic stroke. Furthermore, diabetes mellitus is also associated with higher CRP level and this is the reason for majority stroke patients having diabetes mellitus. Indepth study in CRP levels and its regulation should be conducted.

HOW TO CITE THIS ARTICLE: Subbarayan MK. Chinnaiyan P, Sampati S. Study of high specific C-reactive protein in acute ischaemic stroke. J. Evolution Med. Dent. Sci. 2019;8(15):1243-1247, DOI: 10.14260/jemds/2019/276

\section{BACKGROUND}

Stroke being a serious neurological disease, is one of the major causes of disability throughout the world. ${ }^{1}$ Of all cases of stroke, ischaemic strokes constitute 85-87 per cent. Spontaneous intracerebral haemorrhage and subarachnoid haemorrhage are caused by haemorrhagic stroke and account for the remainder of cases. Neuro-imaging investigations such as Computed Tomography (CT) and Magnetic Resonance Imaging (MRI) are outstanding techniques in the management of stroke patients, the role biomarkers in supporting the clinical diagnosis of stroke, identifying patients at risk of disease and guiding treatment and prognosis should never be ignored. ${ }^{2}$ Many ischaemic stroke candidate have been identified so far, but however, none are used in clinical practice. Principal causes of ischemic cerebrovascular disease are thrombosis, embolism and focal hype perfusion. These can lead to reduction or an interruption of Cerebral Blood Flow (CBF) that affects neurological function. Sudden onset of hemiparesis in an older person is the typical presentation of ischemic stroke. The extent of collateral flow and the location of occlusion determine the differences in symptoms and signs.

'Financial or Other Competing Interest': None.

Submission 07-05-2018, Peer Review 30-03-2019,

Acceptance 05-04-2019, Published 15-04-2019.

Corresponding Author:

Dr. Madhan Kumar. Subbarayan,

No-4, Chairman Chidambaram Street, West Shanmugapuram,

Villupuram-605602, Tamilnadu, India.

E-mail: madhankumar711@gmail.com

DOI: $10.14260 /$ jemds $/ 2019 / 276$
Atherosclerotic ischemic stroke which occurs without warning in more than $80 \%$ of cases is more common in the elderly. ${ }^{3}$ Transient ischemic Attack (TIA) which occurs a few months before the stroke is an important warning sign.

The pathophysiology of TIA is like that of ischemic heart disease. It is an atherosclerotic plaque in a cerebral artery ulcerates inducing accumulation of platelets and coagulation of fibrin to create thrombus that occludes the artery in arteriosclerosis. Which is induced by hypertension, small penetrating arteries in the deep white matter of the brain are affected creating small infarction known as lacunar infarcts. Patients with atrial fibrillation, nearly 80 per cent of them, myocardial infarction, prosthetic values, rheumatic heart disease and larger artery atheroma (Artery- artery embolus) are more susceptible to embolic ischaemic stroke. Atherosclerosis causes emboli, which can partially or temporally obstruct cerebral arteries triggering TIA. ${ }^{4}$

Infarction (Cellular death) occurs within minutes depending on the severity of the ischaemia, which causes irreversible damage even after the restoration of blood flow. This is known as 'core' of the infarct. The tissue surrounding the core is functionally affected because of reduced circulation but can recover once blood flow is restored. 5 This is termed as ischaemic penumbra of the stroke. However, in many cases it is amenable to treatment up to 12 hours, which is called the 'therapeutic window' open for thrombolysis. All necrotic tissues contain oedema and in large areas of necrosis, massive oedema presses adjacent tissues. This increases intracranial pressure and can trigger herniation of the brain resulting in death within a few days in 80 percent of the cases. 6,7 
Since brain receives 20 per cent of cardiac output at rest, 8 it is highly sensitive to ischaemia. Normal average CBF in adult is nearly $50-55 \mathrm{ml} / 100 \mathrm{~g} / \mathrm{min}$, but during brain ischaemia, reduced CBF causes inadequate delivery of oxygen and glucose, activating the evolution of stroke path physiology process, path physiology of ischaemic stroke generally occurs in two stages ${ }^{9}$ molecule- 1 , and vascular cell adhesion molecule, which facilitate migration of mononuclear cells and T lymphocytes into the vessel wall and they a play a major role in the atherosclerotic plaque formation. ${ }^{10}$ Release of superoxide anion and stimulation of tissue factor activity are aided by CRP. CRP also induces plasminogen Activator Inhibitor-1(PAI-1), which is a marker of disrupted fibrinolysis and atherothrombosis. In addition, CRP is likely to increase the possibility of endothelial cells lysis and plaque erosion and can precipitate acute ischaemic stroke or coronary syndrome. All of them trigger atherosclerosis in cerebral and cardiac circulation.

Hs -CRP has been to be associated with acute stroke as a marker of infection and inflammation. Infectious and inflammatory diseases are more common in India than they are in the western countries. ${ }^{11}$ Increased concentration of acute-phase reactants, particularly C - reactive protein (CRP), are indicative of future cardiovascular morbidity. Elevated CRP as well as fibrinogen and serum myeloid a protein, present the future risk of myocardial infarction in patients with stable and unstable angina. ${ }^{12-14}$ CRP concentration correlates with cardiovascular risk indicators in a primary care population. ${ }^{15}$ These observations strengthen the view that CRP can be useful clinical marker in the development of unstable atherosclerotic disease and an indicator of future of cardiovascular morbidity and mortality. Many case-control studies on ischaemic stroke patients that revealed that recent infections are a possible risk factor for ischaemic stroke.16 ischaemic brain injury which is secondary to arterial occlusion is characterized by acute local inflammation and changes in levels inflammatory cytokines in body fluids of human patients. ${ }^{17}$ Many patients with elevated CRP levels within 72 hours of stroke have an increased risk of mortality. However, clinical data pertaining to CRP to prognosis of ischaemic stroke is sparse.

\section{Aim of The Study}

To evaluate highly specific C-reactive protein in acute ischaemic stroke as a prognostic tool.

\section{METHODS}

The observational study was conducted a detailed examination of clinical profile for neurological defect such as aphasia, cranial nerve palsies, limb weakness, sensory impairment, cerebellar dysfunction, conjugate gaze, hemianopia was elicited by bed side neurological examination. Risk factors for cardiovascular events like smoking, hyperlipidaemia, hypertension, diabetes, oral contraceptive usage were recorded. Complete haemogram, urine analysis, ECG, blood sugar, blood urea and serum creatinine were recorded. Fasting blood sample for cholesterol, LDL, VDL, Triglycerides and HDL were recorded. Blood for C-reactive protein was collected within 24 to 48 hours of admission. C-reactive protein was measured qualitatively by semiqualitative latex agglutination test with spectrometry. CRP levels were classified into three groups:
CRP levels is $<1 \mathrm{mg} / \mathrm{l}$, person has a low risk of developing cardiovascular disease. CRP levels are between 1-3 mg/l, person has an average risk.

Data for this study were collected from 100 patients admitted in a tertiary care teaching hospital, following an acute ischaemic stroke or hemiplegia confirmed by computed tomography (CT) scan. The subjects were asked a series of questions pertaining to the disease pattern and risk factors for cardiovascular disease. Interview with each participant lasted for around 30 minutes. Data collection went on for a period of the data collected was recorded. Subsequently, it was compiled and analysed using appropriate statistical tests. Informed written consent was obtained from all the study participants. Institute ethical committee clearance certification was obtained before the study was begun. The sample size estimation was also done at conveniences.

\section{Statistical Methods}

Data entry was done using MS excel 2013 and exported into SPSS 22.0 version for analysis. Continuous variables are expressed as the mean \pm standard deviation (Mean \pm SD) and categorical variables as proportions. Chi-square analysis was used to find the association between categorical variables. Logistic regression models the relationship between a dependent and one or more independent variables. $\mathrm{P}<0.05$ was considered statistically significant.

\section{RESULTS}

It is observed that $60 \%$ of the patients belong to male. Further $63.6 \%$ of the female patients have $<10.1 \mathrm{mg} / \mathrm{L}$ level while $66.7 \%$ of the male patients have $>=10.1 \mathrm{mg} / \mathrm{L}$. Since $\mathrm{p}$ value of 0.010 which is less than 0.05 , hence there is an association between gender and hsCRP. It is observed that $21 \%$ of the patients belong to less than $38,55-64,65-76$ age group. Further $31.8 \%$ of $39-54$ age group patients have $<10.1$ $\mathrm{mg} / \mathrm{L}$ level while $23.1 \%$ of the male patients have $>=10.1$ $\mathrm{mg} / \mathrm{L}$. Since $\mathrm{p}$ value of 0.573 which is greater than 0.05 , hence there is no association between gender and hsCRP. It is observed that $68 \%$ of the patients don't have diabetes mellitus. Further $90.9 \%$ and $61.5 \%$ of $<10.1 \mathrm{mg} / \mathrm{L}$ level and $>=10.1 \mathrm{mg} / \mathrm{L}$ level of the patients don't have diabetes mellitus. Since p value of 0.009 which is less than 0.05 , hence there is an association between diabetes mellitus and hsCRP. It is observed that $63 \%$ of the patients don't have cholesterol level. Further $90.9 \%$ and $61.5 \%$ of $<10.1 \mathrm{mg} / \mathrm{L}$ level and $>=10.1 \mathrm{mg} / \mathrm{L}$ level of the patients don't have cholesterol level. Since $\mathrm{p}$ value of 0.002 which is less than 0.05 , hence there is an association between cholesterol level and hsCRP. It is observed that $74 \%$ of the patients don't have hypertension. Further $90.9 \%$ and $69.2 \%$ of $<10.1 \mathrm{mg} / \mathrm{L}$ level and $>=10.1$ $\mathrm{mg} / \mathrm{L}$ level of the patients don't have hypertension. Since $\mathrm{p}$ value of 0.041 which is less than 0.05 , hence there is an association between hypertension and hsCRP. It is observed that $67 \%$ of the patients don't smoking. Further $95.5 \%$ and $59 \%$ of $<10.1 \mathrm{mg} / \mathrm{L}$ level and $>=10.1 \mathrm{mg} / \mathrm{L}$ level of the patients don't smoking. Since p value of 0.001 which is less than 0.05 , hence there is an association between smoking and hsCRP. It is observed that $66 \%$ of the patients don't have alcoholic. Further $90.9 \%$ and $59 \%$ of $<10.1 \mathrm{mg} / \mathrm{L}$ level and $>=10.1 \mathrm{mg} / \mathrm{L}$ level of the patients don't have alcoholic. Since $\mathrm{p}$ value of 0.005 which is less than 0.05 , hence there is an association between alcoholic and hsCRP. It is observed that $72 \%$ of the patients don't have Ischemic Heart Disease. 
Further $90.9 \%$ and $66.7 \%$ of $<10.1 \mathrm{mg} / \mathrm{L}$ level and $>=10.1$ $\mathrm{mg} / \mathrm{L}$ level of the patients don't have Ischemic Heart Disease. Since $p$ value of 0.025 which is less than 0.05 , hence there is an association between Ischemic Heart Disease and hsCRP. It is observed that $32 \%$ of the patients belong to GOS. Further $90.9 \%$ of $<10.1 \mathrm{mg} / \mathrm{L}$ level patients have GOS score 5 while $41 \%$ of $>=10.1 \mathrm{mg} / \mathrm{L}$ level of the patients have score 2 . Since $\mathrm{p}$ value of 0.000 which is less than 0.05 , hence there is an association between GOS and hsCRP. It is observed that $64 \%$ of the patients are belongs to GOS group. Further $100 \%$ of $<10.1 \mathrm{mg} / \mathrm{L}$ level patients not belong to GOS group while $82.1 \%$ of $>=10.1 \mathrm{mg} / \mathrm{L}$ level patients are belonging to GOS group. Since p value of 0.000 which is less than 0.05 , hence there is an association between GOS group and hsCRP. It is observed that $79 \%$ of the patients belong to angina. Further $100 \%$ and $73.1 \%$ of $<10.1 \mathrm{mg} / \mathrm{L}$ level and $>=10.1 \mathrm{mg} / \mathrm{L}$ level of the patients have angina. Since p value of 0.006 which is less than 0.05 , hence there is an association between angina and hsCRP.

\begin{tabular}{|c|c|c|c|c|}
\hline \multirow{3}{*}{$\begin{array}{l}\text { Diabetes } \\
\text { Mellitus }\end{array}$} & \multicolumn{2}{|c|}{ hsCRP } & \multirow{3}{*}{ Total } & \multirow{3}{*}{$\begin{array}{c}\mathbf{p} \\
\text { Value }\end{array}$} \\
\hline & $\begin{array}{c}<10.1 \mathrm{mg} / \mathrm{L} \\
(\mathrm{n}=22)\end{array}$ & $\begin{array}{c}>=10.1 \mathrm{mg} / \mathrm{L} \\
(n=78)\end{array}$ & & \\
\hline & \multicolumn{2}{|c|}{ n (\%) } & & \\
\hline No & $20(90.9)$ & $48(61.5)$ & $68(68.0)$ & \multirow{3}{*}{$0.009^{* *}$} \\
\hline Yes & $2(9.1)$ & $30(38.5)$ & $32(32.0)$ & \\
\hline Total & $22(100.0)$ & $78(100.0)$ & $\begin{array}{c}100 \\
(100.0)\end{array}$ & \\
\hline \multicolumn{5}{|c|}{ Table 1. Association Between Diabetes Mellitus \& hsCRP } \\
\hline \multicolumn{5}{|c|}{ Chi-square: $6.803,{ }^{* *} \mathrm{p}<0.0$} \\
\hline
\end{tabular}

\begin{tabular}{|c|c|c|c|c|}
\hline \multirow{3}{*}{$\begin{array}{c}\text { Raised } \\
\text { Cholesterol } \\
\text { Level }\end{array}$} & & RP & \multirow{3}{*}{ Total } & \multirow{3}{*}{$\begin{array}{c}\mathbf{p} \\
\text { Value }\end{array}$} \\
\hline & $\begin{array}{c}<10.1 \mathrm{mg} / \mathrm{L} \\
(\mathrm{n}=22)\end{array}$ & $\begin{array}{c}>=10.1 \mathrm{mg} / \mathrm{L} \\
(n=78)\end{array}$ & & \\
\hline & \multicolumn{2}{|c|}{$n(\%)$} & & \\
\hline No & $20(90.9)$ & $43(55.1)$ & $63(63.0)$ & \multirow{3}{*}{$\begin{array}{c}0.002 \\
* *\end{array}$} \\
\hline Yes & $2(9.1)$ & $35(44.9)$ & $37(37.0)$ & \\
\hline Total & $22(100.0)$ & $\begin{array}{c}78 \\
(100.0)\end{array}$ & $\begin{array}{c}100 \\
(100.0)\end{array}$ & \\
\hline
\end{tabular}

Table 2. Association Between Cholesterol Level \& hsCRP

Chi-Square: $9.425,{ }^{* *} \mathrm{p}<0.01$

\begin{tabular}{|c|c|c|c|c|}
\hline \multirow{3}{*}{$\begin{array}{l}\text { Hyper- } \\
\text { tension }\end{array}$} & & CRP & \multirow{3}{*}{ Total } & \multirow{3}{*}{ p Value } \\
\hline & $\begin{array}{c}<10.1 \mathrm{mg} / \mathrm{L} \\
(\mathrm{n}=22)\end{array}$ & $\begin{array}{c}>=10.1 \mathrm{mg} / \mathrm{L} \\
(n=78)\end{array}$ & & \\
\hline & \multicolumn{2}{|c|}{ n (\%) } & & \\
\hline No & $20(90.9)$ & $54(69.2)$ & $74(74.0)$ & \multirow{3}{*}{$0.041^{*}$} \\
\hline Yes & $2(9.1)$ & $24(30.8)$ & $26(26.0)$ & \\
\hline Total & $22(100.0)$ & $78(100.0)$ & $\begin{array}{c}100 \\
(100.0)\end{array}$ & \\
\hline \multicolumn{5}{|c|}{ Table 3. Association Between Hypertension \& hsCRP } \\
\hline \multicolumn{5}{|c|}{ Chi-Square: $4.191,{ }^{*} \mathrm{p}<0.05$} \\
\hline
\end{tabular}

\begin{tabular}{|c|c|c|c|c|}
\hline & \multirow{2}{*}{$\mathbf{p}$ Value } & \multirow{2}{*}{\begin{tabular}{c|c} 
Exp \\
(B)
\end{tabular}} & \multicolumn{2}{|c|}{$\begin{array}{c}\text { 95\% CI for EXP } \\
\text { (B)) }\end{array}$} \\
\cline { 4 - 5 } & & Lower & Upper \\
\hline $\begin{array}{c}\text { Ischemic Heart } \\
\text { Disease }\end{array}$ & $0.028^{*}$ & 2.804 & 1.117 & 7.040 \\
\hline Constant & 0.000 & 0.309 & & \\
\hline Table 4. Association Between Ischemic Heart Disease \& \\
Group \\
\hline \multicolumn{4}{|c|}{ Dependent Variable: Group, p<0.01 } \\
\hline
\end{tabular}

\begin{tabular}{|l|c|c|c|c|}
\hline & \multirow{2}{*}{$\mathbf{p}$ Value } & Exp & \multicolumn{2}{|c|}{ 95\% CI for Exp (B) } \\
\cline { 4 - 5 } & & (B) & Lower & Upper \\
\hline Smoking & 0.610 & 1.263 & 0.515 & 3.100 \\
\hline Constant & 0.001 & 0.396 & & \\
\hline Table 5. Association between Smoking and Group \\
\hline \multicolumn{3}{|c|}{ Dependent Variable: Group, p<0.01 } \\
\hline
\end{tabular}

\begin{tabular}{|c|c|c|c|c|}
\hline & \multirow{2}{*}{ p Value } & \multirow{2}{*}{$\begin{array}{c}\text { Exp } \\
\text { (B) }\end{array}$} & 95\% CI for Exp (B) \\
\cline { 3 - 5 } & & 1.784 & 0.737 & 4.322 \\
\hline Alcoholic & 0.200 & 1.00 & Upper \\
\hline Constant & 0.000 & 0.347 & & \\
\hline Table 6. Association between Alcoholic and Group \\
\hline \multicolumn{3}{|c|}{ Dependent Variable: Group, p<0.01 } \\
\hline
\end{tabular}

\begin{tabular}{|c|c|c|c|c|}
\hline & $\mathbf{p}$ & Exp & \multicolumn{2}{|c|}{$\mathbf{9 5 \%}$ CI or Exp (B) } \\
\cline { 4 - 5 } & Value & (B) & Lower & Upper \\
\hline Angina & 0.488 & 1.481 & 0.488 & 4.498 \\
\hline Constant & 0.023 & 0.313 & & \\
\hline Table 7. Association Between Angina and Group \\
\hline \multicolumn{3}{|c|}{ Dependent Variable: Group, p<0.01 } \\
\hline
\end{tabular}

\section{DISCUSSION}

The observational study was undertaken with objectives to evaluate C-reactive protein as a prognostic tool in ischaemic stroke and to compare $\mathrm{C}$-reactive protein with lipid profile as morbid predictors in ischaemic stroke. A type of methodology was adopted in this research to study to evaluate C-reactive protein as a prognostic tool in ischaemic stroke and to compare C-reactive protein with lipid profile as morbid predictors in ischaemic stroke. An observational study was conducted to examine the acute ischaemic stroke patients in a region against their CRP levels for stroke prognosis. The subjects were patients with acute ischaemic stroke. Hemiplegia which is secondary to ischaemic stroke were included in the study.

CRP, an acute phase protein, increases during systemic inflammation. New evidence suggest that CRP could have a direct influence the inflammatory effects. The present study showed that majority patients (62\%) had CRP level greater than $10.1 \mathrm{mg} / \mathrm{L}$ while only 38 percent of the patients are $<=10.1 \mathrm{mg} / \mathrm{L}$. Previous studies have indicated varying results. Muir et al ${ }^{18}$ had found out increased CRP ( $>10 \mathrm{mg} / \mathrm{L}$ ) levels in 96 out of the $228(42.1 \%)$ patients with acute ischemic stroke in the UK and this result in contrary with the present result because in the present study majority of the people showed greater than $10.1 \mathrm{mg} / \mathrm{L}$. Furthermore, Chaudhuri et al ${ }^{19}$ performed a prospective study, more than three fifths of Indian patients with acute ischemic stroke had high hsCRP (> $3 \mathrm{mg} / \mathrm{l}$ ) levels and Di Napoli et al 1095 patients (74.2\%) with acute ischemic stroke had high CRP levels ( $>0.5 \mathrm{mg} / \mathrm{dl})$ at admission. However, these studies had taken different standard value compared to the present study. Furthermore, the present study showed significant relation between gender and CRP. Several studies Rost et $\mathrm{al}^{20}$ and Bos MJ et $\mathrm{al}^{21}$ showed an association between high CRP and risk for future stroke; however the association was not strong enough to use CRP for individual stroke prediction. The present study indicating significant relation between high CRP and risk for future stroke. Among patients with diabetes some risk factors affect together to enhance the severity of ischaemic stroke.22-24 The interaction between diabetes and stroke is a two different interaction and this influences the tight 
connection between these two diseases which often develop together. In the present result, showed majority of the people don't have diabetes mellitus, however, stroke patients with diabetes mellitus having majority in greater than $10.1 \mathrm{mg} / \mathrm{L}$ level of CRP. This result showing Previous studies have shown that raised levels of serum CRP are associated with obesity and insulin resistance.25,26 Karki study27 also showed positive association between baseline serum CRP and diabetes mellitus incidence.

Stroke patients with hypertension and their CRP level showed significant relation with hypertension. Stroke patients with hypertension seems to be majority having greater than $10.1 \mathrm{mg} / \mathrm{L}$ level of CRP. Majority of stroke patients with smoking and alcoholic habit showed greater than $10.1 \mathrm{mg} / \mathrm{L}$ level of CRP. When compared to nonsmokers, smokers are at double the risk of occurrence of stroke. Stroke risks associated with alcohol consumption include alcohol-induced hypertension, reduced cerebral blood flow, hypercoagulable state and atrial fibrillation. In stroke prevention, lipid management remains to be a vital component. Several meta-analyses have corroborated the benefits of statins in stroke prevention in patients with coronary heart disease. ${ }^{28}$ Cholesterol and Recurrent Events study reported that when patients with moderate cholesterol treated with pravastatin after a myocardial infarction, they were at lower risk of stroke than patients who received placebo. Evidence from research report that lipid peroxidation and infection such as cytomegalovirus may induce a pro-inflammatory cytokine cascade leading to CRP release. ${ }^{29}$

Increased concentration of acute-phase reactants, particularly C-Reactive Protein (CRP), are indicative of future cardiovascular morbidity. Cerebrovascular ischaemia is acknowledged as a major health problem, which causes morbidity and mortality. CRP can be useful clinical marker in the development of unstable atherosclerotic disease and an indicator of future risk of cardiovascular morbidity and mortality. People with cholesterol levels above $200 \mathrm{mg} / \mathrm{dl}$ and cardiovascular risk factors should have a complete lipid analysis total cholesterol, HDL, triglycerides and LDL. They are most likely to benefit from cholesterol-reducing treatment which includes statins. ${ }^{30}$ CRP also associates with prevalent hypertension and with markers of arterial stiffness and end-organ damage in hypertensive patients, and serum CRP is a useful biomarker that predicts overall vascular health in these patients. Stroke risk factors such as arterial hypertension $(\mathrm{AH})$, diabetes mellitus (DM), and lipid metabolism disorders may be controlled by regulating CRP levels.

\section{CONCLUSIONS}

Regulating the level of CRP will help in decreasing the risk of acute schematic stroke. The study concludes that high hsCRP level predicts the chance of acute ischaemic stroke. Furthermore, diabetes mellitus was also related to higher CRP level, and this is the reason for majority of stroke patients having diabetes mellitus. In-depth study of CRP levels and its regulation should be done.

\section{REFERENCES}

[1] Roger VL, Go AS, Lloyd-Jones DM, et al. Heart disease and stroke statistics--2012 update: a report from the
American Heart Association. Circulation 2012;125(1):e2-e220.

[2] Saenger AK, Christenson RH. Stroke biomarkers: progress and challenges for diagnosis, prognosis, differentiation and treatment. Clin Chem 2010;56(1):21-33.

[3] Wittenauer R, Smith L. Background Paper 6.6 Ischaemic and Haemorrhagic Stroke. Priority Medicines for Europe and the World "A Public Health Approach to Innovation". 2012.

[4] Adams HP Jr, Adams RJ, Brott T, et al. Guidelines for the early management of patients with ischemic stroke: a scientific statement from the Stroke Council of the American Stroke Association. Stroke 2003;34(4):1056-83.

[5] Abe 0, Aoki S, Shirouzu I, et al. MR imaging of ischemic penumbra. European Journal of Radiology 2003;46(1):67-78.

[6] Gupta R, Connolly ES, Mayer S, et al. Hemicraniectomy for massive middle cerebral artery territory infarction: a systematic review. Stroke 2004;35(2):539-43.

[7] Morley NC, Berge E, Cruz-Flores S, et al. Surgical decompression for cerebral oedema in acute ischaemic stroke. Cochrane Database Syst Rev 2002;(3):CD003435.

[8] Mishra LD. Cerebral blood flow and anaesthesia: a review. Indian J Anaesth 2002;46(2):87-95.

[9] Mui K, Yoo A, Verduzco L, et al. Cerebral blood flow thresholds for tissue infarction in patients with acute ischemic stroke treated with intra-arterial revascularization therapy depend on timing of reperfusion. American Journal of Neuroradiology 2011;32(5):846-51.

[10] Di Napoli M, Schwaninger M, Cappelli R, et al. Evaluation of C-reactive protein measurement for assessing the risk and prognosis in ischemic stroke: a statement for health care professionals from the CRP Pooling Project members. Stroke 2005;36:1316-29.

[11] Padmalatha PN. High sensitive C-reactive protein in cerebrovascular ischemia. Journal of Evolution of Medical and Dental Sciences 2016;5:449-52.

[12] Thompson SG, Kienast J, Pyke SD, et al. Hemostatic factors and the risk of myocardial infarction or sudden death in patients with angina pectoris. European Concerted Action on Thrombosis and Disabilities Angina Pectoris Study Group. The New England Journal of Medicine 1995;332(10):635-41.

[13] Liuzzo G, Biasucci LM, Gallimore JR, et al. The prognostic value of C-reactive protein and serum amyloid a protein in severe unstable angina. The New England Journal of Medicine 1994;331(7):417-24.

[14] Berk BC, Weintraub WS, Alexander RW. Elevation of Creactive protein in "active" coronary artery disease. Am J Cardiol 1990;65(3):168-72.

[15] Mendall MA, Patel P, Ballam L, et al. C reactive protein and its relation to cardiovascular risk factors: a population based cross sectional study. BMJ 1996;312(7038):1061-5.

[16] Bova IY, Bornstein NM, Korczyn AD. Acute infection as a risk factor for ischemic stroke. Stroke 1996;27(12):2204-6. 
[17] Wang PY, Kao CH, Mui MY, et al. Leukocyte infiltration in acute hemispheric ischemic stroke. Stroke 1993;24(2):236-40.

[18] Muir KW, Weir CJ, Alwan W, et al. C-reactive protein and outcome after ischemic stroke. Stroke 1999;30(5):981-5.

[19] Chaudhuri JR, Mridula KR, Umamahesh M, et al. High sensitivity C-reactive protein levels in acute ischemic stroke and subtypes: a study from a tertiary care center. Iranian Journal of Neurology 2013;12(3):92-7.

[20] Rost NS, Wolf PA, Kase CS, et al. Plasma concentration of C-reactive protein and risk of ischemic stroke and transient ischemic attack: the Framingham study. Stroke 2001;32(11):2575-9.

[21] Bos MJ, Schipper CMA, Koudstaal PJ, et al. High serum C-reactive protein level is not an independent predictor for stroke: the Rotterdam Study. Circulation 2006;114(15):1591-8.

[22] Bangalore S, Kumar S, Lobach I, et al. Blood pressure targets in subjects with type 2 diabetes mellitus/impaired fasting glucose: observations from traditional and bayesian random-effects metaanalyses of randomized trials. Circulation 2011;123(24):2799-810.

[23] Collins R, Armitage J, Parish S, et al. MRC/BHF Heart Protection Study of cholesterol-lowering with simvastatin in 5963 people with diabetes: a randomised placebo-controlled trial. Lancet (London, England) 2003;361(9374):2005-16.

[24] Colhoun HM, Betteridge DJ, Durrington PN, et al. Primary prevention of cardiovascular disease with atorvastatin in type 2 diabetes in the Collaborative Atorvastatin Diabetes Study (CARDS): multicentre randomised placebo-controlled trial. Lancet (London, England) 2004;364(9435):685-96.
[25] Festa A, D'AGOStino R Jr, Howard G, et al. Chronic subclinical inflammation as part of the insulin resistance syndrome: the Insulin Resistance Atherosclerosis Study (IRAS). Circulation 2000;102(1):42-7.

[26] Kahn SE, Zinman B, Haffner SM, et al. Obesity is a major determinant of the association of C-reactive protein levels and the metabolic syndrome in type 2 diabetes. Diabetes 2006;55(8):2357-64.

[27] Karki R. Association between serum c-reactive protein and serum gamma-glutamyl transferase with type 2 diabetes in The Kuopio Ischaemic Heart Disease Risk Factor Study. 2017.

[28] Goldstein LB, Adams R, Becker K, et al. Primary prevention of ischemic stroke: a statement for healthcare professionals from the Stroke Council of The American Heart Association. Circulation 2001;103(1):163-82.

[29] Verma S, Yeh ET. C-reactive protein and atherothrombosis--beyond a biomarker: an actual partaker of lesion formation. American Journal of Physiology Regulatory, Integrative and Comparative Physiology 2003;285(5):R1253-6: discussion R12578.

[30] Paciaroni M, Bogousslavsky J. Primary and secondary prevention of ischemic stroke. European Neurology 2010;63:267-78. 